\title{
DINAMIKA EKONOMI ISLAM DI INDONESIA; Telaah Sosio-Historis Teologis Terhadap Bank Muamalat Indonesia
}

\section{Mochamad Parmudi}

Fakultas Ilmu Sosial dan Ilmu Politik Universitas Islam Negeri Walisongo Semarang Email:parmudimochamad@yahoo.com

\begin{abstract}
Bank Muamalat Indonesia (BMI with) is the symbol of the birth of the new banking system (GLBT) which gives the alternative regarding financial management in accordance with the Islamic Sharia. The establishment of the theological orientation in addition to BMI, also can not be separated from the calculation (rationality) behavioral economics. In terms of BMI is as an expression of the orientation of worldliness that is powerful enough to provide a secure banking system options.

Analysis using qualitative methods of descriptive-i.e. not limited to at the level of the collection and compiling of data only. But includes also interpretations as to the meaning of the data obtained in an effort to elucidate the socio historical theological against BMI. Thus, BMI as a manifestation of a very important theological orientation, just as important as when the Muslims consider the manifestation of religious orientation embodied in the form of ritual piety (eg: build the mosque, went on Hajj, and so forth). So, in this context the presence of BMI in sociological proves the existence of close relationships (positive correlation) between the doctrines of religion with the actions/behavior of the economic life of the Muslims.
\end{abstract}

Keywords: the dynamics of, economi, islam, bank, muamalah.

\begin{abstract}
Abstrak
Bank Muamalat Indonesia (selanjutnya disebut dengan BMI) adalah merupakan symbol lahirnya sistem perbankan baru (islami) yang memberikan alternative mengenai pengelolaan keuangan sesuai dengan syariah Islam. Berdirinya BMI selain orientasi teologis, juga tidak bisa dipisahkan dari perhitungan (rasionalitas) perilaku ekonomi. Dalam arti BMI adalah sebagai ekspresi dari orientasi keduniawian yang cukup kuat dalam memberikan pilihan sistem perbankan yang aman.
\end{abstract}

Analisis menggunakan metode deskriptif-kualitatif yaitu tidak terbatas sampai pada tingkat pengumpulan dan menyusun data saja. Tetapi meliputi juga interpretasi mengenai makna data yang diperoleh sebagai upaya untuk 
menelaah sosio historis teologis terhadap BMI. Dengan demikian, BMI sebagai manifestasi orientasi teologis yang sangat penting, sama pentingnya ketika umat Islam menganggap manifestasi orientasi keagamaan yang diwujudkan dalam bentuk kesalehan ritual (misalnya: membangun masjid, pergi haji, dan sebagainya). Jadi, dalam konteks ini kehadiran BMI secara sosiologis membuktikan adanya hubungan yang erat (korelasi positif) antara doktrin agama dengan tindakan/perilaku ekonomi kehidupan umat Islam.

Kata kunci: Dinamika, Ekonomi, Islam, Bank, Muamalah. 


\section{A. Pendahuluan}

Program pembangunan nasional (national development) yang dilaksanakan pada tahapan pembangunan jangka panjang putaran pertama dalam 25 tahun di pertengahan pemerintahan Orde Baru berkuasa diakui atau tidak nyatanya telah memberikan banyak kemajuan dalam meningkatkan taraf hidup bangsa Indonesia. Sekalipun pada akhirnya pemerintahan Orde Baru mengalami kebangkrutan dengan berbagai krisis yang menimpanya; mulai dan krisis finansial, ekonomi dan merembet ke krisis politik yang kemudian melengserkannya.

Kendatipun begitu, sedikit banyak rezim ini juga membawa perbaikan bagi bangsa, terutama kemampuannya untuk mengurangi jumlah angka kemiskinan rakyat Indonesia. Padahal dibandingkan zaman sebelumnya, yakni di masa pemerintahan Orde Lama justru angka kemiskinan penduduk mengalami peningkatan drastis. Pemerintahan Orde Lama memang terlalu menekankan orientasi pembangunan politik sehingga bidang ekonomi yang semestinya menjadi kebutuhan dasar (basic need) rakyat yang harus segera dipenuhi malah terabaikan. Oleh karena itu kemiskinan penduduk di masa Orde Lama tidak berkurang sebagaimana yang terjadi di masa pemerintahan Orde Baru. Di masa ini justru angka kemiskinan penduduk dapat ditekan seminimal mungkin.

Merujuk angka-angka statistik yang dimiliki oleh Pemerintah Pusat, jumlah penduduk Indonesia yang hidup di bawah garis kemiskinan pun telah berhasil ditekan menjadi (tinggal) sekitar 27 juta orang. Jika saja, hitungan kasar $85 \%$ dan jumlah penduduk Indonesia tersebut adalah umat Islam berarti paling tidak ada sejumlah 23 juta umat Islam yang masih hidup di bawah garis kemiskinan. ${ }^{1}$ Data ini menunjukkan jumlah umat Islam yang hidup dalam kemiskinan adalah yang terbesar (lima kali lipat) dibanding umat-umat dan agama lain yang secara kasar jumlahnya dihitung cuma 4 juta berbanding 23 juta.

Selain mereka yang masih di bawah garis kemiskinan itu, terdapat pula lebih dan 2,5 juta penduduk (per-rumah tangga) yang bermata pencaharian sebagai pedagang kecil. Keberadaan mereka tersebar di seluruh nusantara dengan konsentrasi di pulau Jawa. Mereka itu kebanyakan berdagang tanpa disertai surat ijin berbadan hukum sebagaimana aturan usaha yang dikeluarkan

1 Zainul Bahar Noor, Keunggulan BMI terhadap Bank Konvensional, Seminar Sehari Bank Muamalat Sebagai Alternatif Sistem Perbankan Masa Depan Ummat Islam Indonesia, Universitas Gadjah Mada, Fakultas Ekonomi, Yogyakarta., 27 Februari 1993. 
oleh pemerintah kita, bahkan mereka tidak mempunyai tempat usaha yang tetap alias berada dalam kategori sebagai pedagang kaki lima.

Ironis memang, sudah tidak memiliki tempat usaha permanen, seperti warung atau toko untuk menjual barang dagangannya, ditambah masalah dengan tidak dimilikinya surat ijin usaha. Padahal dna masalah inilah yang seringkali dijadikan alasan pokok kenapa pemerintah seringkali melakukan kebijakan tanpa belas kasihan dengan menggusur dan melarang para pedagang kaki lima berjualan di berbagai kota di Tanah Air ini.

Memang, dalam berusaha biasanya para pedagang kaki lima ini menggelar dagangannya di tempat-tempat umum yang dipandang ramai dan strategis, seperti trotoar jalan, taman kota atau di pinggir alun-alun yang kadang-kadang mengganggu masyarakat yang sedang lalu lalang. Namun tidak sedikit juga di antara mereka yang berdagang tanpa mengusik kesibukan orang sesuai yang diijinkan oleh pemerintah, dengan cara berpindah tempat dari satu lokasi ke lokasi lain; dari daerah satu ke daerah lain tergantung ada tidaknya momenmomen atau perhelatan acara keramaian yang digelar oleh daerah-daerah setempat di lokasi-lokasi tertentu, seperti dalam momentum perayaan syawalan, sekatenan atau pameran pembangunan.

Masalahnya kemudian kalau dihitung, misalnya 85\% dan populasi pedagang kaki lima ini beragama Islam, berarti paling tidak ada sekitar 2 juta dan jumlah pedagang kaki lima yang termasuk golongan umat Islam. ${ }^{2}$ Data ini memperlihatkan lagi-lagi umat Islam menjadi golongan terbesar yang berada di sektor usaha kecil dan informal dalam mencari mata pencaharian.

Dari angka-angka ekonomi tersebut menunjukkan mayoritas umat Islam masih berada dalam himpitan sosial dan kemiskinan ekonomi yang cukup mengusik perhatian kita. Tentu angka-angka yang signifikan tersebut bukan berarti kondisi kemiskinan lebih-lebih di era reformasi ini yang masih menghimpit umat Islam khususnya, dan bangsa Indonesia pada umumnya untuk dibiarkan saja, tanpa ada kehendak untuk mengubah atau menolong mereka memperbaiki nasib.

Justru dari sini, persoalan krusial tersebut menjadi tanggung jawab bersama umat Islam sendiri sebagai satu tubuh yang bagian-bagiannya seharusnya saling melengkapi; ibarat suatu bangunan rumah yang masingmasing komponennya; atap, dinding dan pondasi berfungsi saling mengokohkan.

\footnotetext{
${ }^{2}$ Ibid.
} 
Oleh karena keyakinan akan keberadaan umat sebagai satu tubuh atau satu bangunan rumah, maka sudah sewajibnyalah tidak berpangku tangan berdiam diri; duduk manis tinggal di rumah dan hidup mementingkan diri sendiri dan kerabatnya, melainkan untuk selalu bertolong menolong (bekerjasama) sesama umat tanpa memandang asal usul dan kekerabatannya dalam kerangka memperbaiki keadaan buruk tersebut. Bukankah Allah SWT telah berfirman dalam surat A1-Maidah àyat 2 yang artinya kurang lebih; “... bekerjasamalah kalian semua dalam segenap kebajikan dan takwa, dan jangan sekali-kali bekerjasama dalam dosa dan bermusuban"

Sikap tolong menolong tersebut nyatanya tidak hanya berhenti di teks suci al-Qur'an saja melainkan ia menjadi spirit bagi usaha untuk mengkonkretkannya, misalnya dalam tindakan ekonomi. Usaha konkret yang berhubungan dengan perjuangan mengangkat kehidupan ekonomi umat dari lembah kemiskinan dan penderitaan sosial tersebut, antara lain telah diwujudkan melalui pembentukan lembaga keuangan umat yang dikenal dengan nama Bank Muamalat Indonesia; Bank Islam yang pertama di Indonesia. Pada awalnya bank ini didirikan sebagai badan perekonomian yang bertujuan untuk menyediakan dana kepada para pedagang kecil dan anggota majelis pengajian (jemaah masjid), khususnya yang tinggal di ibukota Jakarta.

Lebih dari itu berdirinya Bank Islam ini yang diprakarsai oleh Majelis Ulama Indonesia (MUI) dan ICMI merupakan langkah keterlibatan kongkret kaum ulama dan cendekiawan Indonesia dalam pembangunan perekonomian itu tidak semata-mata untuk kepentingan umat Islam, melainkan juga bagi segenap bangsa dan negara Indonesia, sehingga usaha ini secara nasional menjadi bagian yang tidak terpisahkan dari usaha yang sebenarnya dijalankan oleh BMI sendiri. ${ }^{3}$

Dalam pada itu, agaknya perekonomian nasional kita cenderung bertumpu pada sektor industri pengolahan dan keuangan yang berbasis wilayah perkotaan. Di sektor dan di wilayah inilah umat Islam yang secara ekonomi kelihatannya justru belum siap. Sekarang yang diharapkan adalah kemampuan untuk berperan lebih besar lagi di masa-masa mendatang dengan operasionalisasi Bank Islam yang lebih luas dalam anti berskala nasional. Berdirinya Bank Islam ini, bagimanapun akan memberikan harapan baru dan

3 Abdul Aziz Thaba, Islam dan Negara dalam Politik Orde Baru. (Jakarta: Gema Insani Press, 1996), 289.

Mochamad Prmudi, Dinamika Ekonomi Islam di Indonesia; ... 
dinamika perekonomian nasional sekaligus menjadi sejarah baru bagi umat Islam yang dimulai sejak zaman Orde Baru sampai masa-masa sesudahnya. ${ }^{4}$

Dalam konteks seperti ini, Bank Islam paling tidak dapat memberikan alternatif lembaga keuangan yang baru dan menarik, terutama dalam menawarkan tingkat keuntungan (sistem bagi hasil) dibandingkan dengan keuntungan yang diperoleh berdasarkan suku bunga tabungan (misalnya) yang diberikan oleh bank konvensional (umum) dalam menarik dana di masyarakat.

Dengan demikian bank Islam selayaknya mempersiapkan diri siap dengan tenaga profesional yang mampu menilai kelayakan perusahaan (nasabah) yang akan menjadi mitra usahanya. Selain itu, keprofesionalan tenaga juga diharapkan mampu menganalisis prospek bisnis yang akan dimasukinya. Karena itu, kehadiran Bank islam yang beroperasi secara syari'ah diharapkan menjadi alternatif cara menabung bagi umat Islam tanpa harus khawatir atau ragu-ragu akan status hukum bunga bank, dan dalam mendapatkan kredit (pinjaman dana).

Berdasarkan pokok masalah tersebut di atas, tulisan $\mathrm{ini}^{5}$ disusun dengan alasan guna mengetahui bagaimana sejarah dan doktrin ekonomi syari'ah di Indonesia berkembang dalam konteks perbankan Islam dan implikasinya yang ditimbulkannya bagi perkembangan ekonomi nasional. Sedangkan titik fokus analisis akan ditekankan pada: Pertama, di seputar dinamika perekonomian syari'ah dan manifestasinya dalam konteks realitas sosial-ekonomi di Indonesia. Kedua, melihat sejauh mana relevansi situasi historis tersebut dalam konteks teologis lembaga perekonomian syari'ah, khususnya lembaga perbankan Islam bagi kepentingan umat Islam.

Riset ini menggunakan metode deskriptif-kualitatif; analisis ini mencoba menggambarkan dan menguraikan keadaan suatu obyek berdasarkan faktafakta yang tampak atau sebagaimana adanya. ${ }^{6}$ Usaha mendeskripsikan faktafakta itu pada tahap permulaan tertuju pada upaya mengemukakan gejala-gejala secara lengkap di dalam aspek yang di analisis, agar jelas keadaannya. ${ }^{7}$ Oleh karena itu pada tahap ini fungsinya tidak lebih daripada penggambaran yang

\footnotetext{
${ }^{4}$ Prospek, 14 Maret 1992, 66.

5 Tulisan ini adalah merupakan ringkasan dari hasil penelitian (tesis) saya di BMI dalam rangka untuk memperoleh gelar S2 Magister Sains, Universitas Kristen Satya Wacana Salatiga, 2000.

${ }^{6}$ Hadari Nawawi, Metode Penelitian Bidang Sosial (Yogyakarta: Gadjah Mada University Press), 1998), 63-64.

7 lbid, lihat Sumadi Suryabrata, Metodologi Penelitian Kualitatif (Yogyakarta: PT Raja Grafindo Persada, 1998), 18-19.
} 
bersifat penemuan fakta-fakta seadanya (fact finding) dan mengemukakan hubungan satu (variabel) dengan yang lain di dalam aspek-aspek yang dideskripsikan tentang bank Islam tersebut.

Pada tahap berikutnya analisis akan diberi bobot yang lebih tinggi; dengan memberikan penafsiran yang adequat terhadap fakta-fakta yang ditemukan di lapangan. Dengan kata lain, metode ini tidak terbatas sampai pada tingkat pengumpulan dan menyusun data saja, tetapi meliputi juga analisa interpretasi mengenai makna data yang diperoleh. ${ }^{8}$ Oleh karena itu analisis ini dipandang sebagai upaya untuk memecahkan persoalan dengan mengadakan klasifikasi gejala, menilai gejala, menetapkan hubungan antar gejala yang ditemukan dan seterusnya. ${ }^{9}$

Secara sederhana dapat dijelaskan bahwa metode deskriptif kualitatif merupakan langkah-langkah metodologis dalam melakukan "representasi" obyektif tentang gejala-gejala yang tampak di dalam masalah yang diteliti yang bersumber pada referensi literatur (buku, makalah, surat kabar, majalah dan atau yang sejenis), dari informan utama (key informan) yang menyangkut bank Islam.

Dalam pengumpulan bahan literatur, cara kerjanya dilakukan dengan seleksi studi kepustakaan. Sementara terhadap informan utama, dilakukan dengan cara interview secara langsung disertai pemakaian daftar (draft) pertanyaan yang telah disiapkan dan diberikan kepada informan terlebih dulu. Dari situ, kemudian informan menjawab dalam bentuk tertulis ataupun lisan. Ternyata cara seperti ini dilakukan dapat memudahkan informan utama dalam mencermati pertanyaan-pertanyaan yang telah diajukan serta menjawab atau merespon pertanyaan dengan baik dan tepat.

Para informan utama yang diwawancarai tersebut terdiri dari; tokoh organisasi Islam yang berkompeten (MUI), ahli perbankan Islam/cendekiawan muslim. Data yang diperoleh dari informan utama dipakai untuk mengetahui secara langsung persepsi mereka dalam kaitannya dengan pokok persoalan yang diajukan. Sekalipun demikian, fakta-fakta empirik yang ditemukan dari data yang berhasil dikumpulkan tidak hanya digunakan sekadar membeberkan fakta atau data (secara apa adanya), tetapi ditafsirkan secara kritis untuk menemukan signifikansi maknanya.

Sehubungan dengan pokok pembahasan yang diuraikan di atas, maka pendekatan fenomenologi digunakan dalam menafsirkan "makna" data. Pendekatan fenomenologi itu sendiri secara mudah dimengerti sebagai usaha

\footnotetext{
${ }^{8}$ Bandingkan dengan Lexy Moleong, Metodologi Penelitian Kualitatif, (Bandung: Rosda, 1999), 6.

${ }_{9}$ Bandingkan dengan Anton Bakker, Achmad Charis Zubair, Metodologi Penelitian Filsafat, (Yogyakarta: Kanisius 1992), 54.
} 
memahami secara esensial sesuatu gejala di balik bentuk-bentuk yang penampakannya.

Fenomenologi menunjukkan proses "menjadi" dan kemampuan mengetahui bentuk-bentuk (gejala yang tampak) secara bertahap untuk menuju pengetahuan (makna) yang benar dari obyek yang diamati. Singkatnya, pendekatan ini sebenarnya merupakan analisis deskriptif tentang esensi atau struktur ideal $^{10}$ dari gejala-gejala yang menampakkan diri dalam suatu fakta sosial.

\section{B. Historisitas dan Doktrin Bank Islam}

\section{Ruang Lingkup Ekonomi Islam}

Ilmu ekonomi Islam termasuk bagian dari disiplin ilmu-ilmu sosial yang karakteristiknya didasarkan pada upaya mempelajari masalah-masalah ekonomi rakyat yang diilhami oleh nilai-nilai ajaran agama Islam. Dengan ini tidaklah hendak dikatakan bahwa kaum muslimin dicegah untuk mempelajari masalahmasalah ekonomi non muslim.

Sebaliknya, umat Islam yang hidup diilhami oleh nilai-nilai ajaran agama Islam diperintahkan pula oleh syariat untuk mempelajari masalah-masalah minoritas non muslim dalam sebuah negara Islam khususnya, dan mengenai kemanusiaan pada umumnya. Demikianlah definisi yang kelihatannya sempit ini akan tetapi mempunyai implikasi yang luas. ${ }^{11}$

Ilmu ekonomi Islam dalam konteks ini adalah terutama mengenai permasalahan yang menyangkut kegunaan dan keberadaan uang. Sebenarnya ahli ekonomi yang menyokong pandangan bahwa ilmu ekonomi adalah mengenai perilaku manusia yang berhubungan dengan kegiatan mendapatkan uang dan membelanjakan uang semakin bertambah. Tetapi penulis klasik dan pengikutnya cenderung menyelidiki yang tersirat di belakang selubung keuangan itu dan menggambarkan masalah ekonomi dari segi bukan moneter. Permasalahan ekonomi umat manusia yang fundamental bersumber dari kenyataan bahwa manusia mempunyai kebutuhan dan kebutuhan itu pada umumnya tidak dapat dipenuhi tanpa mengeluarkan daya energi manusia dan sarana yang terbatas. ${ }^{12}$

${ }^{10}$ Noeng Muhadjir, Metodologi Penelitian Kualitatif, (Yogyakarta: Rake Sarasen, 1996), 12-13.

${ }_{11}$ M. Abdul Mannan, Teori dan Praktek Ekonomi Islam (Yogyakarta: PT. Dana Bhakti Wakaf, 1995), 19-22.

12 Lihat Yusuf Qardhawi, Norma dan Etika Ekonomi Islam, Jakarta: Gema Insani Press, 1995), 27 
Pendek kata, dalam ilmu ekonomi Islam tidak hanya mempelajari individu sosial melainkan juga manusia dengan bakat religius. Hal ini disebabkan karena banyaknya kebutuhan dan terbatasnya sarana, maka timbullah masalah ekonomi. ${ }^{13}$ Ekonomi Islam dikendalikan oleh nilai-nilai dasar ajaran agama Islam. Dalam ilmu ekonomi Islam, individu biasanya memperhitungkan perintah yang tercantum dalam teks-teks al-Qur'an danSunnah dalam menjalankan aktivitasnya.

Oleh karena itu, dalam agama Islam kesejahteraan sosial dapat dimaksimalkan jika sumber daya ekonomi juga dialokasikan sedemikian rupa, sehingga dengan pengaturan kembali keadaannya, tidak seorang pun lebih baik dengan menjadikan orang lain lebih buruk di dalam kerangka al-Qur'an dan Sunnah. Karena itu pula, segala sesuatu yang tidak secara nyata terlarang oleh al-Qur'an atau Sunnah tetapi taat asas dengan semangat yang sama boleh dinyatakan Islami.

Dalam sistem ekonomi Islam melakukan kegiatan-kegiatan demikian, tidak dianggap salah. Ilmu ekonomi Islam, tidak hanya aspek perilaku manusia yang berhubungan dengan cara mendapatkan uang dan membelanjakannya, namun sebagian besar ia merupakan bagian dari aktivitas kaum muslimin. ${ }^{14}$

Benar-benar menakjubkan, bahkan lebih dari seribu empat ratus tahun yang lalu, Islam telah mengusahakan keseimbangan yang langgeng antara pendapatan dan pembelanjaan guna mencapai sasaran keuntungan sosial yang maksimum. Islam selalu menekankan agar setiap orang mencari nafkah dengan halal. Semua sarana dalam hal mendapatkan kekayaan secara tidak sah dilarang, karena hal ini, pada akhirnya, dapat membinasakan suatu bangsa (al-Qur'an, an Nisa : 29). ${ }^{15}$

Oleh karena itu, telah ditetapkan aturan-aturan tertentu yang mengatur dan menentukan bentuk dari intensitas kegiatan-kegiatan manusia dalam memperoleh kekayaan. Hal ini begitu dibatasi sehingga serasi dengan kedamaian dan kesejahteraan masyarakat secara keseluruhan. Pada tahap manapun tak ada kegiatan ekonomi yang bebas dari beban pertimbangan moral. Untuk tujuan ini dalam al-Qur'an dikatakan:

13 Bandingkan dengan Syed Nawab Haidar Naqvi, Etika dan Ilmu Ekonomi: Suatu Sintesis Islami, (Bandung: Mizan, 1993), 64-77.

${ }^{14}$ M. Abdul Mannan, Ibid., 21-22

15 Ali Audah, Al-Qur'an Terjemahan dan Tafsirnya, (Jakarta: Pustaka Firdaus, 1993), hlm. 188-189. Lihat Abdullah Yusuf Ali, The Holy Quran Text Translation and Commentary (Brentwood Maryland: Amana Corporation, 1989), 193-194 
"Wabai sekalian manusia makanlah yang halal lagi baik dari apa yang terdapat di bumi, dan janganlah kamu mengikuti langkah-langkah setan karena sesunggubnya setan itu adalah musuh yang nyata bagimu" (al-Baqarah: 168). ${ }^{16}$

Jadi karena itulah Islam sangat tidak menyetujui monopoli sumber daya oleh segelintir manusia kapitalis (al-Quran, al Hasyr: 7) dan tekanannya selalu terletak pada pemanfaatan sosial yang berguna saja, al-Qur'an mengatakan:

"Sesungguhnya orang-orang yang selalu membaca kitab suci Allah dan mendirikan sholat dan menafkabkan sebagian dari rizqi yang Kami anugerabkan kepada mereka dengan diam-diam dan terang-terangan, mereka itu mengharapkan perniagaan yang tidak. akan rugi" (al-Fathir:9).

Sesunggubnya keserakahan dianggap sebagai sifat negatif dan merusak. Kekayaan orang-orang yang kikir, selain hanya memberikan keuntungan bagi mereka juga menjadikan rintangan dan menghalangi pertumbuban moral serta spiritual mereka (alQur'an, Ali-Imron :180), sebaliknya, bidup bermewah-mewahan pun, dikecam. Dalam alQur'an dikatakan:

"Dan janganlah kamu berlebih-lebihan. Sesunggubnya Allah tidak menyukai orang-orang yang berlebib-lebihan"(al-An am:141)

"Sesunggubnya pemboros-pemboros itu adalah saudara-saudara setan, dan setan itu adalah sangat ingkar kepada Tubannya'(al-Isra, 27)

Sesunggubnya Tuban itu tunggal dan serba kecukupan. Manusialah yang serba kekurangan, dan kemakmuran itu dapat dicapai bukan dengan jalan keserakahan atau karena tidak pernah memberi, melainkan dengan memanfaatkan harta demi kepentingan Allah yaitu untuk pengabdian kepada makbluk-makbluknya (al-Qur'an, Mubammad: 38). Dengan cara inilah, Islam mengatur kegiatan-kegiatan memperoleh uang dan mengeluarkan uang sedemikian rupa sehingga dapat meningkatkan kesejahteraan rakyat.

Demikianlah dalam satu arti, ilmu ekonomi Islam amat terbatas. Terbatas karena hanya mengenai orang-orang yang mempunyai keyakinan pada ke-esaan Allah dan ajaran-ajaran moral-Nya, sebagaimana tercermin dalam kitab suci alQur'an dan Sunnah. Juga terbatas, karena suatu negara Islam tidak bisa

\footnotetext{
16 Ayat-ayat al-Qur'an ditulis terjemahannya saja dengan maksud untuk memudahkan teknis penulisan (mempersingkat halaman). Semua terjemahan mengacu kepada Ali Audah, al-Qur'an Terjemahan dan Tafsirnya (Jakarta: Pustaka Firdaus, 1993)
} 
mendorong setiap hal termasuk ekonomi dalam hal ini kegiatan-kegiatan ekonomi yang tidak meningkatkan kesejahteraan manusia sudah pasti tidak dapat didorong.

Namun konsep kesejahteraan manusia itu tidak mungkin statis dan mandeg, melainkan ia selalu relatif pada keadaan yang sebenarnya senantiasa berubah. Pokok persoalannya adalah bahwa konsep kesejahteraan harus sejalan dengan prinsip-prinsip universal Islam itu sendiri sebagai ajaran agama.

Sekali lagi hal ini berarti memiliki arti yang luas karena ilmu ekonomi Islam mengambil pengetahuan dan faktor-faktor non ekonomi seperti faktor politik, sosial, etika, dan moral. Demikianlah ruang lingkup ilmu ekonomi Islam yang tampaknya menjadi administrasi kekurangan sumber-sumber daya dalam masyarakat manusia dipandang dari segi konsepsi etik kesejahteraan dalam Islam.

Oleh karena itu, ekonomi Islam tidak hanya mengenai sebab-sebab material kesejahteraan, tetapi juga mengenai hal-hal non material yang tunduk kepada larangan Islam tentang konsumsi dan produksi. ${ }^{17}$ Dalam Islam baik konsumen maupun produsen bukanlah "raja". Perilaku keduanya harus dituntun oleh kesejahteraan umum, individual dan sosial sebagaimana dipahami dalam syariat.

\section{Asal Usul Ekonomi Islam}

Maksud utama sub bagian ini adalah untuk menyusun hipotesis bahwa prinsip fundamental ilmu ekonomi Islam bersumber pada al-Qur'an dan Sunnah. Tafsiran dan penafsiran kembali asas-asas ini (yang mengatur berbagai pokok persoalan) seperti nilai, sistem harga, konsumsi dan produksi, kekuatan permintaan dan penawaran, dan sebagainya, oleh sejumlah ahli ekonomi Islam telah diberi dasar operasional ilmu ekonomi Islam dan kesinambungan ide-ide ekonominya sejak awal mula Islam.

Cendekiawan muslim seperti Abu Yusuf (731-798), Yahya Ibnu Adam (meninggal 818), El Hariri (1054-1122), Tusi (1201-1274), Ibnu Taimiya (12621328), Ibnu Khaldun (1332-1406), Shah Waliullah (1702-1763), Al Ghazali (1059-1111), Al Farabi (meninggal 950) dan banyak lainnya yang telah menyumbang perkembangan ilmu pengetahuan ekonomi (Islam).

\footnotetext{
${ }^{17}$ Lihat Yusuf Qardhawi, Norma dan Etika Ekonomi Islam, (Jakarta: Gema Insani Press 1995), 97-170.
} 
Di sini penulis hanya menyebutkan secara singkat sumbangan pemikiran dari masing-masing di antara cendekiawan itu. Sumbangan Abu Yusuf terhadap keuangan umum yang paling berharga ialah tekanannya pada peranan keuangan bagi eksistensi negara, pekerjaan umum dan perkembangan pertanian. Sementara gagasan Ibnu Taimiyah ${ }^{18}$ tentang "harga ekuivalen", pengertiannya terhadap ketidaksempurnaan pasar dan pengendalian harga, tekanannya pada peranan negara untuk menjamin dipenuhinya kebutuhan pokok rakyat, dan idenya tentang hak milik, memberikan sejumlah petunjuk penting tentang teori kebijakan ekonomi Islam pada zamannya.

Definisi Tusi, misalnya dalam karya beliau yang berbahasa Persia AkblaqI- Nasiri, menulis: 'Bila setiap orang harus tekun untuk menghasilkan makanan, pakaian, rumah dan alat-alatnya sendiri .. tentu dia tidak akan tahan akan punya makanan dalam jangka waktu lama yang diperlukan (untuk menyediakan barang-barang tersebut di atas).... Tetapi, karena orang bekerja sama satu dengan yang lainnya dan setiap orang melakukan profesinya yang khusus dengan menghasilkan konsumsi yang lebih dari cukup untuk dirinya sendiri, dan karena bukum keadilan mengawasi hal-bal mengenai pertukaran produksi kelebihan seorang dengan orang lainnya maka sarana ekonomi dan barang-barang menjadi tersedia bagi semua orang ..... Dengan demikian Tuban dalam kebijaksanaan-Nya membedakan aktivitas dan cita rasa orang sedemikian rupa; sehingga mereka mungkin melakukan pekerjaan yang berbeda (untuk saling membantu). Pembagian kerja inilah yang menimbulkan adanya struktur internasional dan sistem ekonomi umat manusia. Karena dengan adanya manusia tidak akan terdapat suatu bentuk tanpa adanya kerja sama timbal balik, hal itu tidak akan terjadi tanpa kontak sosial. Maka kodrat manusia adalah tergantung pada masyarakat".

Sedangkan Ibnu Khaldun, cendekiawan Arab dan Tunisia, yang diakui sebagai Bapak ilmu-ilmu sosial, memberikan definisi bagi ilmu ekonomi yang lebih luas ruang lingkupnya daripada definisi Tusi di atas. Referensi Ibnu Khaldun tentang "ketentuan akal dan etika" memperhatikan bahwa dia menganggap ilmu ekonomi sebagai ilmu pengetahuan yang positif dan normatif. Selanjutnya digunakan kata "massa" (aljumbur) menunjukkan kenyataan bahwa maksudnya mempelajari ilmu ekonomi tidak lain adalah

${ }^{18}$ Shaykh al Islam Ibnu Taimiyah, seorang ahli teologi Hambali adalah seorang sarjana yang terkenal tentang sejarah Islam. Pandangan-pandangan ekonominya sebagian besar dinyatakan dalam karya-karyanya yang termasyhur al Siyasah al Syariah Fi Ishlah al Raiwal Rai'ab (Hukum publik dan privat) dalam Islam terjemahan dalam bahasa Inggris oleh Faruk Omar, terjemahan dalam bahasa Perancis oleh Henri Laoust) Demikian juga Al Hisbab wa Mas'ulsyah al Hukumah al Islamiyah (pengawasan umum terhadap kegiatan-kegiatan ekonomi dan sosial serta peran negara Islam). 
untuk meningkatkan kebutuhan kesejahteraan massa, bukan demi kesejahteraan individu. Hal ini karena hukum ekonomi dan sosial berlaku pada massa tidak dapat dipengaruhi oleh individu. Ibnu Khaldunlah yang telah melihat adanya hubungan timbal balik antara faktor-faktor ekonomi, politik, sosial, etika dan pendidikan dalam sebuah peradaban suatu bangsa. Walaupun karyanya yang terkenal Al-Muqaddimah membahas faktor-faktor ini secara terpisah-pisah namun dia menganggap semuanya ini sebagai "aspek peradaban yang mempengaruhi manusia dalam organisasi sosial mereka" yang saling berkaitan. Dia memperkenalkan sejumlah gagasan ekonomi yang mendasar seperti pentingnya diferensiasi kerja, sistem harga, pembentukan modal dan sebagainya. ${ }^{19}$

Secara keseluruhan, para cendekiawan muslim pada umumnya dan Ibnu Khaldun pada khususnya dapatlah dianggap sebagai pelopor perdagangan, fisiokrat dan penulis klasik (seperti misalnya, Adam Smith, David Ricardo, Malthus) dan penulis neo klasik (misalnya Keynes) ${ }^{20}$

\section{Doktrin Riba dalam Al-Qur'an}

Sebelum membahas lebih jauh mengenai bank ada baiknya terlebih dahulu untuk menjelaskan riba dan sejarah pelarangan riba. Kata riba berasal dan bahasa Arab, yang secara etimologis berarti "tambahan" (ziyadah) atau "kelebihan". Pendapat lain mengatakan riba berarti perbuatan mengambil harta orang lain tanpa adanya imbalan yang memadai. Ada beberapa ayat Al-Quran yang mempunyai anti tambahan. Misalnya surah Al-Hajj (22:5):

... Dan kamu lihat bumi itu kering, kemudian apabila telah Kami turunkan air di atasnya, biduplab bumi itu dan suburlah dan Menumbubkan Berbagai macam tumbubtumbuban yang indah.

Arti kata riba dalam surah ini adalah bertambahnya kesuburan atas tanah. Sejalan dengan ini, bisa juga dilihat surah An-NahI (16:92):

"... disebabkan adanya satu golongan yang lebib banyak, jumlahnya (arba) dari golongan yang lain"

Ada juga yang mencatat surah Al-Haqqah (69:10):

"... Lalu Allah menyiksa mereka dengan siksaan yang keras (al-rabiyah)"

\footnotetext{
${ }^{19}$ Rosenthal, The Muqaddimah, An Introduction to History, oleh Ibnu Khaldun (Routledge and Kegan Paul, London, 1967), lihat Mukti Ali, Filsafat Islam tentang Sejarab (Jakarta: Tintamas, 1976), 97-125.

${ }^{20}$ M. Abdul Mannan, Ibid., 23-25
} 
Pengertian di atas masih sangat umum sifatnya, dan belum menentukan jenis riba apa yang diharamkan. Larangan riba, dalam al-Qur'an terdapat dalam beberapa surah yaitu antara lain:

\section{A1-Baqarah (2:275) ditambah 278-279.}

A1-baqarah :275:

orang-orang yang Makan (mengambil) riba[174] tidak dapat berdiri melainkan seperti berdirinya orang yang kemasukan syaitan lantaran (tekanan) penyakit gila. Keadaan mereka yang demikian itu, adalah disebabkan mereka berkata (berpendapat), Sesunggubnya jual beli itu sama dengan riba, Padahal Allab telab menghalalkan jual beli dan mengharamkan riba. orang-orang yang telah sampai kepadanya larangan dari Tubannya, lalu terus berhenti (dari mengambil riba), Maka baginya apa yang telah diambilnya dabulu (sebelum datang larangan); dan urusannya (terserab) kepada Allah. orang yang kembali (mengambil riba), Maka orang itu adalah penghuni-penghuni nerake; merek a kekeal di dalamnya.

Dan arti ayat Al-Baqarah 278-279 adalah:

"Hai orang-orang yang beriman, bertakwalah kepada Allah dan tinggalkan sisa Riba (yang belum dipungut) jike kamu orang-orang yang beriman. Maka jika kamu tidak mengerjakan (meninggalkan sisa riba), Maka ketabuilab, bahwa Allab dan Rasul-Nya akan memerangimu. dan jika kamu bertaubat (dari pengambilan riba), Maka bagimu pokok hartamu; kamu tidak Menganiaya dan tidak (pula) dianiaya."

\section{Surah 'All 'Imran (3:130-131):}

"Hai orang-orang yang beriman janganlah kamu memakan riba dengan berlipat ganda dan bertaqwalah kamu kepada Allah Swt supaya kamu mendapat keberuntungan. Dan peliharalah dirimu dan api neraka yang disediakan untuk orangorang yang kafir."

\section{Surah An-Nisa (4:160-161}

"Maka disebabkan kelaliman orang-orang Yabudi, Kami haramkan atas mereka (memakan makanan) yang baik-baik (yang dabulunya) dibalalkean mereka, dan karena mereka banyak menghalangi manusia dari jalan Allah Swt. Dan disebabkan mereka memakan riba padahal sesunggubnya mereka telah dilarang, dan karena mereka memakan harta orang dengan jalan batil, Kami telah menyediakan untuk. orang-orang kafir di antara mereka itu sisa yang pedib " 


\section{Surah Ar-Rum (30:39):}

'Dan suatu riba (tambahan) yang kamu berikan agar dia menambah pada barta manusia; maka riba itu tidak menambah pada sisi Allah. Dan apa yang kamu berikan berupa zakat yang kamu maksudkan untuk mencapai keridhaan Allah, maka (yang berbuat demikian) itulah orang-orang yang melipat gandakan (pabalanya)".

Dengan memperhatikan ayat-ayat tersebut di atas, ada ayat yang secara tegas mengharamkan riba. Ada juga yang memang tegas melarangnya, tetapi masih berupa gambaran umum dan belum mencakup secara menyeluruh. Dilihat dan periodisasi turunnya wahyu, ayat-ayat itu mempunyai masa yang berbeda. Ada ayat yang diturunkan di Makkah, masa awal perjuangan Islam, ketika ajaran-ajarannya lebih banyak menekankan pada masalah tauhid (teologi). Ada juga ayat-yang diturunkan di Madinah.

Dari perspektif ini terlihat ada tahapan-tahapan pelarangan, seperti tahapan pelarangan minuman keras (khamr). Dengan kata lain, dalam mengobati patologi sosial, Al-Qur'an menggunakan cara yang bertahap; berangsur-angsur. Seperti pelarangan dalam riba, Al-Qur'an tidak secara langsung menilai hukumnya haram, tetapi menggunakan teori bertahap dan berangsur sedikit demi sedikit.

Konsep riba tidak terbatas pada bunga. Dikenal dua bentuk riba dalam hukum Islam. Yaitu al-Qarud yang berhubungan dengan tambahan atas pinjaman, dan riba al-Buyu yang berhubungan dengan tambahan atas jual-beli. Riba al Buyu ada dua bentuk yakni riba al-fadl yang meliputi penukaran secara bersamaan dan komoditas yang sama yang memiliki kualitas atau kuantitas yang tidak sama, dan riba an-nasiah yang meliputi pertukaran secara tidak bersamaan dan komoditas yang sama yang memiliki kualitas dan kuantitas yang sama. Pelarangan berlaku bagi objek-objek yang dapat diukur atau ditimbang dan dari jenis yang sama. Kelebihan dalam kuantitas maupun penundaan dalam pelaksanaan, dua-duanya dilarang.

Riba al-qauid bunga pinjaman, meliputi beban atas pinjaman yang bertambah seiring dengan berjalannya waktu. Dengan kata lain merupakan pinjaman berbunga, dan kadang-kadang disebut sebagai riba an-nasiah, 
tambahan karena menunggu. Riba ini muncul apabila peminjam harta orang lain, apapun bentuknya dibebani oleh si pemberi pinjaman untuk membayar suatu tambahan tertentu di samping pokok pinjaman pada saat pelunasan. Jika tambahan itu ditetapkan sebelumnya pada awal transaksi sebagai suatu jumlah tertentu, dengan cara bagaimanapun pertambahan ini terjadi, maka pinjaman itu menjadi pinjaman ribawi. Pelarangan diperluas ke semua bentuk pinjaman dan atau utang yang memberikan tambahan kepada si kreditur.

\section{Islam dan Perbankan}

'Orang-orang yang makan (mengambil), riba tidak dapat berdiri melainkan seperti berdirinya orang yang kemasukan syaitan lantaran (tekanan) penyakit gila. Karena mereka yang demikian itu disebabkan mereka berkata (berpendapat), sesunggubnya jual beli itu sama dengan riba, padahal Allah telah menghalalkan jual beli dan mengharamkan riba. Orang-orang yang telah sampai kepadanya larangan dari Tubannya lalu terus berbenti (dari mengambil riba), maka baginya apa yang telah diambilnya dabulu (sebelum datang larangan) dan urusannya (terserah) kepada Allah. Orang yang mengulangi (mengambil riba) maka orang itu adalah penghuni neraka, mereka kekal di dalamnya (Q.S. alBaqarah :275)

Ayat tersebut di ataslah yang menjadi landasan teologis untuk pijakan penafsiran perbankan dalam Islam. Dalam kehidupan sehari-hari hampir setiap orang mengerti apa yang disebut bank. Tetapi apa yang dimaksud bank dan apa yang menjadi tanda bahwa sesuatu itu adalah bank? Berbagai penulis buku perbankan tidak selalu sama dalam memberikan arti atau definisi bank. ini, karena perbedaan situasi dan kondisi dan suatu negara, juga karena bank merupakan perusahaan yang dinamis sehingga gambaran tentang bank mengalami perubahan. Pada taraf ini barangkali perlu untuk menjelaskan konsep mengenai perbankan secara etimologi maupun fungsi-fungsi perbankan dalam Islam. 
Kata bank diambil dan kata "banko" dalam bahasa Italia. ${ }^{21}$ Pada masa yang lalu, para penukar uang (money changer) melakukan pekerjaan mereka di pelabuhan-pelabuhan di tempat para kelasi-kelasi kapal datang dan pergi. Mereka meletakkan uang penukaran itu di atas sebuah meja di hadapan mereka dan meja ini dinamakan "bangko" yaitu "bangku" dalam bahasa Indonesia. ${ }^{22}$

Istilah ini berpindah ke negeri-negeri lain dengan arti yang sama dan mempunyai fungsi yang sama pula. Bangsa Arab pun memakai kata-kata tersebut dalam arti yang serupa dengan pengertian bahwa bank ${ }^{23}$ itu adalah suatu perusahaan hidup yang melaksanakan fungsi keuangan.

Munculnya bank bermula dari perkembangan cara penyimpanan harta benda. Para pedagang yang sering berpindah tempat merasa khawatir membawa perhiasan emas, uang dan lain sebagainya. Bank adalah suatu tempat yang dipercaya aman dan terjaga. Oleh karena itu, kepercayaan publik pun semakin meningkat/tertarik dengan adanya bank.

Pertama kali bank berdiri di kota Venesia dan Genoa (Italia) sekitar abad ke-14. Kota-kota tersebut sangat terkenal dengan sebutan kota dagang. Para pedagang menuju kota-kota itu untuk mengadakan barter (transaksi tukar menukar barang dagangan). Dari kedua kota itulah, sistem perbankan pindah ke Eropa Barat (Inggris) yaitu berdirinya Bank of England pada tahun 1696.

Seiring dengan dinamika kehidupan manusia, bank sangat diperlukan teutama dalam usaha memajukan kepentingan nasional dan internasional. Bank telah mengikat 'jurusan' hidup manusia sebagai urat nadi dari perusahaanperusahaan, pedagang, petani, pegawai, dan sebagainya. Jadi, bank merupakan lapangan muamalat ${ }^{24}$

${ }^{21}$ Fuad Muhammad Fachruddin, Riba dalam Bank, Koperasi dan Asuransi (Bandung; PT Al Ma'arif, 1985), 109

22 Bank dalam arti Exchange of Currencies; merupakan satu fungsi dari Baitul Mal Islam yang dilakukan oleh bagian Dewan al Amal. Sistem ini dijalankan oleh Muawiyah I (41-404) dan juga Daulah Abbasiyah (Aa. Duri, Studies on the Economic life of Mesopotamia in the $10^{\text {th }}$ Century, Baghdad $1367 \mathrm{H}$ dengan mengeluarkan paper money (wesel).

${ }^{23}$ Dalam bahasa Arab kata Bank disebut dengan Masharaf.

${ }^{24}$ Muamalat berasal dari bahasa Arab yang digunakan dalam istilah Islam untuk hubungan yang diadakan oleh manusia di bidang tukar-menukar manfaat demi kepentingan hidup manusia (kemaslahatan umat). Bahkan Nabi Muhammad Saw. menjelaskan dan menegaskan bahwa agama Islam itu adalah muamalat yakni cara berbuatnya manusia terhadap manusia lainnya. 


\section{Universalitas Bank Islam}

Ada sebagian orang Islam berpendapat bahwa perbankan Islam tidak dapat dipraktekkan, karena hal ini akan mengucilkan suatu negara Islam dari dunia lainnya (teralienasi), sehingga mengakibatkan kerugian besar dalam perdagangan internasionalnya. Tapi bila memungkinkan bagi bangsa yang berlainan di dunia baik dalam prinsip politik dan ekonominya untuk hidup berdampingan, dan jika Amerika Serikat dan Palestina atau Rusia dan negaranegara Arab bisa membuat perjanjian perdagangan, maka penulis tidak menemukan alasan mengapa negara Islam harus terpisah dan bagian dunia lainnya. Misalnya, Indonesia menerapkan prinsip sistem perbankan Islam karena mayoritas penduduknya beragama Islam. Jadi bisa saja dalam satu negara ada dua sistem (perekonomian), seperti di RRC

Jauh dari penyebab kerugian dalam perdagangan internasional, perbankan Islam akan meningkatkan volumenya. Ini, disebabkan bank moderen membiayai perdagangan luar negeri dengan menerima dan mengumpulkan surat wesel yang ditarik oleh para pelanggan, mentransaksikan usaha devisa lainnya, dan menerima suatu komisi sebagai balas jasa untuk pelayanan mereka. Tetapi dalam sistem Islami, bank akan memberikan semua pelayanan ini tanpa balas jasa apa pun karena persekutuan mereka dengan para pengusaha. Lagi pula, bank sebagai mitra usaha akan membantu pengusaha untuk menghindari spekulasi yang tidak ekonomis sehingga permintaan suplai komoditi dapat disesuaikan untuk membawa kemakmuran ekonomi suatu negara dan dunia secara keseluruhan. ${ }^{25}$

Akhirnya, prinsip perbankan Islam itu universal karena sangat sejalan dengan prinsip-prinsip perbankan internasional semata-mata karena dunia modern sadar atau tidak sadar, sebenarnya sedang mengarah pada filsafat ekonomi perbankan Islam. Kecenderungan ini, dalam bantuan-bantuan keuangan dunia diakui dengan terbentuknya "International Development Association (IDA)" pada tanggal 24 September 1960, sebagai afiliasi "International Bank of Reconstruction and Development (IBRD)" atau bank dunia.

\footnotetext{
${ }^{25}$ Ibid., 178
} 
IDA akan memulai sebagai suatu dana yang menyebar karena ia akan memberikan pinjaman sekaligus dengan suku bunga nol persen dalam kasus perkecualian, tergantung pada faktor politik dan ekonomi dalam setiap negara penerima. ${ }^{26}$

\section{Bank Islam di Indonesia}

\section{Sejarah Berdirinya Bank Muamalat Indonesia}

Ide konkrit pendirian Bank Islam berawal dari lokakarya "Bunga Bank dan Perbankan" yang diselenggarakan MUI pada tanggal 18-20 Agustus 1990 di Cisarua. Ide ini kemudian lebih dipertegas lagi. dalam Munas IV MUI di Hotel Sahid Jaya Jakarta tanggal 22-2 5 Agustus 1990. Atas dasar amanat Munas IV MUI inilah langkah untuk mendirikan Bank Islam di Indonesia dimulai. ${ }^{27}$

Tidak lama setelah Munas IV, MUI membentuk Kelompok Kerja (Pokja) untuk mempersiapkan segala sesuatunya, yang diketuai oleh Prodjo Kusumo, Sekretaris Jenderal MUI. Untuk kelancaran pelaksanaan tersebut, Tim Pokja membentuk Tim Kecil "Penyiapan Buku Panduan Bank Tanpa Bunga", yang diketuai oleh Dr. Ir. M. Amin Azis, dengan anggota Syahrul Ralie Siregar, A. Malik, SE, dan Zainulbahar Noor, SE, Tim Kecil ini kemudian di perkuat dengan masuknya Jr. Abdul Aziz Kuntoadji, Drs. Amin R. Batubara, Drs. Karnaen Perwataatmaja, MPA, Drs. Fuadi Mourad, Chalid Hsb, BA, Jimly Asshiddiqie, MA dan Abdul Mughni, MBA. ${ }^{28}$

Hal paling utama yang dilakukan oleh Tim Perbankan MUI di samping melakukan pendekatan-pendekatan dan konsultasi dengan pihak terkait adalah menyelenggarakan pelatihan calon staf melalui "Management Development Program" di LPPI, Jakarta yang dibuka pada tanggal 29 Maret 1991 oleh Menteri Muda Keuangan Drs. Nasrudin Sumintapura, MA.

Dukungan politik Presiden Soeharto waktu itu sebagai pemrakarsa pendirian bank bagi hasil syari'ah pertama di Indonesia ini, serta peran pribadi beberapa mantan Menteri dan Menteri Kabinet Pembangunan V seperti misalnya Ir. Hartarto, Dr. Arifin M. Siregar, Ir. Azwar Anas dalam proses

\footnotetext{
${ }^{26}$ Ibid., 179 lihat juga Sudin Haron, 100-125.

27 Anonim, Laporan Tahunan BMI 1995 (Jakarta: tp), 1995

${ }^{28}$ Prospek, 2 Nopember 1991,73-74
} 
pendiriannya telah semakin memantapkan pelaksanaan rencana tersebut. Demikian pula keberhasilan sisi pengumpulan dana yang tidak akan tercapai sedemikian rupa tanpa peran aktif para pengusaha muslim, antara lain: Dr. Sukamdani Sahid Gitosardjono, Probosutedjo, Muhammad (Bob) Hasan, Abdul Latief Agus, Sudwikatmono, E. Kowara, Hutomo Mandala Putra, Ir. Abu Rizal Bakrie dan banyak lagi yang tercantum dalam daftar 227 pemegang saham pendiri Bank Islam (hampir sebagian daripadanya adalah keseluruhan Menteri Muslim Kabinet Pembangunan V). ${ }^{29}$

Momentum sejarah yang perlu dicatat adalah bahwa pertama, kesediaan "Yayasan Amal Bhakti Muslim Pancasila" meminjamkan dananya tanpa imbalan apapun sebagai modal yang dibutuhkan untuk setoran pertama dalam pengajuan izin Prinsip Pendirian Bank Islam di Indonesia. Kedua, keberadaan Ikatan Cendekiawan Muslim Indonesia (ICMI) khususnya peran pribadi Prof. Dr. Ing. B.J. Habibie yang mendorong secara lebih jauh demi realisasinya Bank Muamalat Indonesia (BMI). Beberapa tim telah dibentuk yaitu: Tim Pendanaan, Tim Hukum dan Tim Anggaran Dasar, yang masing-masing diketuai oleh Dr. Ir. M. Amin Aziz dengan dukungan Nasrudin Sumintapura, M.A., Drs. Karnaen Perwataatmaja, MPA dan Drs Rachmat Saleh. Dalam tim terakhir diikutsertakan Drs. Omar Abdalla, Widarsa Dipradja, Somala Wiria, Drs. Amir F. Batubara dan Drs. Robby Djohan. Sebagian besar dari mereka yang terlibat dalam proses awal pendirian Bank Muamalat Indonesia, yaitu 23 diantaranya, merupakan pemrakarsa di mana Presiden Soeharto sebagai pemrakarsa pertama, begitu pula Sudharmono, $\mathrm{SH}^{30}$

Setelah lebih kurang setahun tercetusnya ide mendirikan bank syariah tersebut, dengan memanjatkan puji syukur ke hadirat Allah SWT., pada tanggal 1 November 1991 terlaksana penandatanganan Akte Pendirian PT. Bank Muamalat Indonesia sebagai Bank Islam pertama di Sahid Jaya Hotel di hadapan Notaris Yudo Paripurno, SH dengan Akte Notaris No. 1 Tanggal 1 November 1991 (Izin Menteri Kehakiman No. C2.2413.HT.O1.O1 tanggal 21 Maret 1992/ Berita Negara RI Tanggal 28 April 1992 No. 34). ${ }^{31}$

29 Hal iadalah ni sebagai indikasi manuver politik menjelang Pemilu Juni 1992 untuk memperoleh dukungan umat Islam; lihat Editor No. 22/ Th.VI/20 Februari 1993, 19.

${ }^{30}$ Prospek, Ibid.

${ }^{31}$ Ibid. 
Pada saat penandatanganan Akte Pendirian ini terkumpul komitmen pembelian saham sebanyak Rp 84 Milyar. Dua hari berselang, Minggu tanggal 3 November 1991, masyarakat Jawa Barat diundang oleh Presiden Soeharto di Istana Bogor dalam acara Silaturahmi Bapak Soeharto dan Masyarakat Jawa Barat Dalam Rangka Penjualan Saham Pendirian Bank Islam". ${ }^{32}$ Dari hasil acara Istana Bogor, modal dasar Rp 500 Milyar pada tahap awal dapat dipenuhi dengan total komitmen modal disetor sebesar Rp.106.126.382.00,00. Dengan angka modal awal ini Bank Muamalat mulai beroperasi pada 1 Mei 1992, per SK Menteri Keuangan. RI No. 1223/MK.013/1991 tanggal 5 November 1991, diikuti oleh Izin Usaha Keputusan Menteri Kenangan RI No. 430/KMK:013/1992 tanggal 24 April 1992.

Pada Jum'at, 27 Syawal 1412 H, bertepatan dengan tanggal 1 Mei 1992, Menteri Keuangan dan dengan dihadiri oleh Gubernur Bank Indonesia, meresmikan mulai beroperasinya BMI sebagai Bank Islam dalam upacara "Soft Opening” yang diadakan di kantornya di Gedung Arthaloka, Jl. Jend. Sudirman No. 2 Jakarta.

Acara resmi "Grand Opening" diadakan pada dua minggu setelah itu, Jumat 12 Dzulkaidah 1412 H bertepatan dengan 15 Mei 1992 di Pun Agung Sahid Jaya Hotel. Peresmian tersebut diawali dengan sambutan tertulis Presiden Soeharto dan sambutan Wakil Presiden Sudharmono, S.H, yang sekaligus menandatangani prasasti berdirinya bank Islam pertama di Indonesia yang dioperasikan sesuai dengan syariah. ${ }^{33}$

Rapat Umum Pemegang Saham Luar Biasa yang pertama dilaksanakan pada hari Senin, 3 Rabiul Awal 1412H, bertepatan dengan tanggal 31. Agustus 1992 dengan acara pokok, "Pengukuhan Susunan Pengurus Bank Muamalat". Rapat Umum Pemegang Saham berikutnya telah dilangsungkan pada hari Kamis, 26 Dzulhijjah 1413 H, bertepatan dengan 17 Juni 1993, bertempat di Pun Agung Sahid Jaya Hotel Jakarta, sedangkan Rapat Umum Pemegang Saham berikutnya telah dilaksanakan di tempat yang sama pada tanggal 19 Dzulhijjah 1414 H bertepatan dengan 30 Mei 1994, masing-masing dengan acara pokok antara lain "Laporan Tentang Jalannya Perseroan dan Hasil yang Telah Dicapai Dalam Tahun Buku yang Bersangkutan dan Penambahan Anggota Direksi" memenuhi ketentuan pasal 18 dan pasal 19 Akte Pendirian

\footnotetext{
32 Ibid.

33 Anonim, Ibid.
} 
Bank Muamalat RUPS pada tanggal 22 Maret 1995 masing-masing dengan acara pokok "Laporan Tentang Jalannya Perseroan dan Hasil yang Telah Dicapai dalam Tahun Buku yang Bersangkutan dan Pergantian Manajemen BMI” yang masa kepengurusannya berakhir bulan Nopember 1996.

\section{Bentuk Bank Islam}

BMI sebagai Bank Islam pertama di Indonesia didirikan dalam bentuk sebuah. Perseroan Terbatas yang didirikan di bawah KUHD, berdasarkan akta pendirian tanggal 1 November 1991 dan Notaris Yudo Paripurno, SH di Jakarta. Pada tanggal 21 Maret 1992 mendapat pengesahan sebagai Badan Hukum PT berdasarkan SK Menteri Kehakiman RI (Ismail Saleh) No. C2.2413.HT.O1.O1 tahun 1992, untuk menjalankan perniagaan Bank bagi basil di bawah UU No. 7 tahun 1992 tentang Undang-undang Pokok Perbankan, berdasarkan SK Menteri keuangan RI J.B. Sumarlin) No. 430/KJvIK.013/1992. ${ }^{34}$

Bank mempunyai komitmen modal sebanyak lebih kurang 196 Milyar. Para pemegang sahamnya adalah 227 pemegang saham pendiri ditambah sekitar 800 ribu pemegang saham biasa. Bank Muamalat Indonesia terdaftar di Bapepam sebagai perusahaan publik yang non listed pada tanggal 28 Oktober 1993 dan efektif perusahaan publik berdasarkan Surat Ketua Bapepam (Bacelis Ruru) No. S-1860/PMI/1993.

Para pemegang saham memilih Dewan Komisaris dan Dewan Direksi dalam "Rapat Umum Pemegang Saham" tahunan untuk melaksanakan dan menjalankan operasi Bank. ${ }^{35}$ BMI juga mempunyai Dewan Pengawas Syari'ah yang bertugas untuk menentukan apakah Bank itu beroperasi dalam semua bidang menurut hukum-hukum syariah atau tidak.

Kantor pusat BMI terletak di Jalan Thamrin di kawasan "segi tiga emas" Jakarta Pusat, dan telah membuka cabang-cabangnya secara berangsur-angsur dan hampir merata di seluruh tempat di negara kesatuan Republik Indonesia .

34 M. Ruslim Karim (Editor), Berbagai Aspek Ekonomi Islam, (Yogyakarta: Tiara Wacana, 1992), 157-164

${ }^{35}$ Lihat lampiran, Prinsip Management Bank Tanpa Bunga 
Dalam operasionalmya BMI juga menyediakan berbagai jasa lainnya yang biasa disediakan oleh Bank- Bank perniagaan dan tidak bertentangan dengan hukum Islam. Berikut ini cukup disebutkan beberapa contoh saja dari jasa-jasa tersebut : ${ }^{36}$

(i) Pengiriman dan pemindahan uang.

(ii) Jual beli mata uang asing.

(iii) Pengurusan investasi.

(iv) Jasa pemegang amanah (trustee) dan jasa nominee (nominee company)

\section{Kesimpulan}

Berdasarkan pada tahap-tahap pembahasan tentang Dinamika Ekonomi Islam di Indonesia (Sebuah Telaah Sosio Historis Teologis Terhadap Bank Muamalat Indonesia) maka dapat ditarik kesimpulan bahwa Bank Muamalat Indonesia adalah merupakan symbol lahirnya sistem perbankan baru (islami) yang memberikan alternative mengenai pengelolaan keuangan sesuai dengan syariah Islam.

Berdirinya BMI selain orientasi teologis, juga tidak bisa dipisahkan dari perhitungan (rasionalitas perilaku ekonomi). Dalam arti BMI adalah sebagai ekspresi dari orientasi keduniawian yang cukup kuat dalam memberikan pilihan sistem perbankan yang aman.

Dengan demikian, BMI sebagai manifestasi orientasi teologis yang sangat penting, sama pentingnya ketika umat Islam menganggap manifestasi orientasi keagamaan yang diwujudkan dalam bentuk kesalehan ritual (misalnya: membangun masjid, pergi haji, dan sebagainya). Jadi, dalam konteks ini kehadiran BMI secara sosiologis membuktikan adanya hubungan yang erat (korelasi positif) antara doktrin agama dengan tindakan/perilaku ekonomi kehidupan umat Islam.

${ }^{36}$ M. Rusli Karim, Ibid, 165-170

Mochamad Prmudi, Dinamika Ekonomi Islam di Indonesia; ... 


\section{DAFTAR PUSTAKA}

\section{A. Buku-Buku}

Abdullah, Taufiq, ed., Agama, Etos Kerja dan Pembangunan Ekonomi, LP3ES, Jakarta, 1988.

LP3ES, Jakarta, 1987.

Islam dan Masyarakat: Pantulan Sejarah Indonesia,

Adeney, Frances S., and John Titaley, Social Theory: A Course Reader, PPsAM, UKSW, Salatiga, 1992.

Aghnides, N.P., Mohammeden Theories of Finance with an Introduction Mohammeden Law, the Premier Boox House, Lahore, 1980.

Ahmad, Muhdlor, Etika dalam Islam, Al-Ikhlas, Surabaya (tt).

Andreski, Stanislav, Max Weber: Kapitalisme, Birokrasi dan Agama, alih bahasa: Hartono, Tiara Wacana, Yogyakarta, 1998.

Anonim, Laporan Tabunan BMI, Jakarta, 1995.

Azhar, Basyir Ahmad, Garis Besar Sistem Ekonomi Islam, BPFE., UGM, Yogyakarta, 1987

Aziz, Thaba Abdul, Islam dan Negara dalam Politike Orde Baru, Gema Insani Press, Jakarta 1996.

Berger, Peter, Langit Suci, LP3ES, Jakarta, 1994.

Black, James A. and Champion Dean J., Methode dan Masalab Penelitian Sosial, terjemahan: E, Koesworo, Eresco, Bandung, 1992.

Bucaille, Maurice, Bibel, Qur'an dan Sains Modern, Bulan Bintang, Jakarta, 1978.

Budiman, Arief, Sistem Perekonomian Pancasila dan Ideologi Ilmu Sosial di Indonesia, Gramedia, Jakarta, 1989.

Dahril, Tengku, dkk., Al-Qur'an, IPTEK dan Kesejahteraan Umat, Universitas Islam Riau Press, 1994.

Edi, Swasono Sri, Terobosan Kultural dalam Ekonomi Kita, Dekopin, Jakarta, 1990.

Fuad, Mohamad Fachruddin, Riba dalam Bank, Koperasi, Perseroan dan Asuransi, Alma'arif, Bandung, 1985.

Gauhar, Altaf, Tantangan Islam, Pustaka, Bandung, 1983. 
Guntur, Waseso Mulyadi, Kekuasaan, Birokrasi, Harta, dan Agama di Mata Max Weber dan Emile Durbeim, Hanindita, Yogyakarta, 1987.

Haron, Sudin, Prinsip dan Operasi Perbankan Islam, Berita Publishing, Sdn., Bhd., Malaysia, 1996.

Hendropuspito, D., Sosiologi Agama, Kanisius, Yogyakarta, 1983.

Holland, Joe and Henriot, Peter, Analisis Sosial dan Refleksi Teologis, Kanisius, Yogyakarta, 1994.

Haidar, Naqvi, Syed Nawab, Etika dan Imu Ekonomi: Suatu Sintesis Islami, Mizan, Bandung, 1993.

Husain, Haikal Muhammad, Sejarah Hidup Mubammad, Litera Antar Nusa, Jakarta, 1996.

Iqbal, M., The Reconstruction of Religious Thought in Islam, Lahore, Pakistan, 1996.

JOI, Ihalauw John, Bangunan Teori, UKSW, Salatiga, 1985.

Kahf, Monzer, Ekonomi Islam: Telaah Analitik Terhadap Fungsi Sistem Ekonomi Islam, Pustaka Pelajar, Yogyakarta, 1995.

Lubis, Ibrahim, Ekonomi Islam, Jakarta, 1994.

Mursyid, Prihantono dan Basyaib, Hamid, Bank Tanpa Bunga, Mitra Gema Widya, Yogyakarta, 1993.

Perwataatmadja, Karnen, dan Syafi'i Antonio, Muhammad, Apa dan Bagaimana Bank Islam, Dana Bhakti Wakaf, Yogyakarta, 1992.

Qardhawi, Yusuf, Norma dan Etika Ekonomi Islam, Gema Insani Press, Jakarta, 1996.

Rahardjo, Dawam, Etika Ekonomi dan Manajemen, Tiara Wacana, Yogyakarta, 1990.

Raharja, Prathama, Uang dan Perbankan, Rineka Cipta, Bandung, 1990.

Rahman, F. Islamic Methodology in History, Islamic Research Institute, Islamabad, Pakistan, 1966.

Rosenthal, F., The Muqaddimah, an Introduction History by Ibnu Kahaldun, Routledge and Kegan Paul, London 1997.

Rusli, Karim, Berbagai Aspek Ekonomi Islam, Fak. Ekonomi UII, Yogyakarta, 1992.

Quraish, Shihab, M., Membumikan Al-Qur'an, Mizan, Bandung, 1992. , Wawasan Al-Qur'an, Mizan, Bandung, 1996. 
Sobary, Mohammad, Kesalehan dan Tingkah Laku Ekonomi, Benteng Budaya, Yogyakarta, 1995.

Stoddard, Loothrop, Dunia Baru Islam, Jakarta, 1966.

Undang-Undang Perbankan Nomor.7 Tabun 1992, Rasindo, Jakarta, 1995.

Umar, Nuruddin, Klasfikasi Ayat Al-Qur'an: Pedoman Mencari Ayat Al-Qur'an, Al-Ikhlas, Surabaya, 1982.

Weber, Max, The Protestant Ethic and The Spirit of Capitaliusm, Unwin Hyman, London, 1989.

Wahid, Abdurrahman, Muslim di Tengah Pergumulan, Lappenas, Jakarta, 1981.

Yusuf, Ali 'Abdullah, The Holy Qur'an, Text, Translation, and Commentary, Amana Corporation, Brentwood, Maryland, USA., 1989.

\section{B. Majalah dan Surat Kabar}

Editor, Nomor.22/Thn.VI/20 Februari 1993

Prospek, 14 Maret 1992

Republika, 2 Juli 1993

Suara Merdeka, Minggu 12 Mei 1996

TEMPO, 6 April 1991

Ummat, Nomor. 20/Thn.1/1 April 1996

, Nomor. 22/Thn.1/29 April 1996

, Nomor. 20/Thn.1/22 Juli 1996 